Received 28.10.2016 Reviewed 01.12 .2016 Accepted 14.12.2016

A - study design

B - data collection

C - statistical analysis

D - data interpretation

E - manuscript preparation

F - literature search

\section{Drought monitoring in the Seybouse basin (Algeria) over the last decades}

\author{
Amina KHEZAZNA ${ }^{1) \text { ABCEF }}$, Hocine AMARCHI ${ }^{1)}$ ABCF, \\ Oussama DERDOUS ${ }^{2) \mathrm{CDEF}}$, Fouad BOUSAKHRIA ${ }^{1) \mathrm{ABC}}$
}

\footnotetext{
${ }^{1)}$ Badji Mokhtar University, Faculty of Engineering Sciences, Department of Hydraulics, BP 12, 23000 Annaba, Algeria; e-mail: a.khezazna@gmail.com, amarchihocine@yahoo.fr, foued.boussakhria@univ-annaba.org

2) Kasdi Merbah University, Faculty of Applied Sciences, Department of Civil Engineering and Hydraulic, Route Ghardaïa, BP 511, Ouargla, 30000, Algeria; e-mail: oussamaderdous@hotmail.fr
}

For citation: Khezazna A., Amarchi H., Derdous O., Bousakhria F. 2017. Drought monitoring in the Seybouse basin (Algeria) over the last decades. Journal of Water and Land Development. No. 33 p. 79-88. DOI: 10.1515/jwld2017-0022.

\begin{abstract}
Algeria is amongst the African countries most affected by climate change impacts especially by drought which caused considerable economic losses in the past decades. In this paper, drought monitoring for the period between 1970 and 2011 was conducted in the Seybouse watershed by analysing annual rainfall data in terms of variability and trends along with the calculation of the standardized precipitation index $(S P I)$. The results indicated important inter-annual rainfall fluctuation and a significant increasing trend. The estimated drought indices indicated that the Seybouse watershed experienced in the past a long dry period with a moderate severity followed by a long wet period at the majority of the study area. Moreover, the interpolation of the standardized precipitation indices $(S P I)$ on the entire Seybouse basin in GIS allowed visualizing and evaluating the spatial-temporal evolution of drought in the region which should help the decision-makers in the management of water resources, agriculture and other activities that may be affected by drought.
\end{abstract}

Key words: climate change, drought, GIS, Seybouse watershed, standardized precipitation index (SPI)

\section{INTRODUCTION}

Drought is one of the most important natural hazards that presented a serious problem for human societies and ecosystems across generations. According to WILHITE and GLANTZ [1985] drought is classified into four categories: (i) Meteorological drought; defined as a lack of precipitation for a period of time over the affected area; (ii) Hydrological drought defined as an insufficiency in surface and subsurface water resources supply; (iii) Agricultural drought refers to a period with soil moisture deficit, which affects the crop productivity; (iiii) Socioeconomic drought is associated with insufficient water resources supply to satisfy the economic needs in the affected region.

To face this hazard, men tried to appreciate the phenomenon by trying to understand the climate cycles through the study of the variability and the trends of different climatic variables especially rainfall and temperatures [BALLING et al. 1998; HE, GAUTAM 2016; NICHOLSON 1989; VINNIKOV et al. 1990; ZHAI, PAN 2003].

Since 1900, several indices were developed to identify and to assess the severity of drought, such as the rainfall anomaly index (RAI) [VAN ROOY 1965], the Palmer drought severity index (PDSI) [PALMER 1965], and the standardized precipitation index (SPI) [MCKEE et al. 1993; 1995] this latter is recommended 
by many organizations such as the World Meteorological Organization (WMO) and the United States National Oceanic and Atmospheric Administration (NOAA) for characterizing meteorological droughts as well as the other categories of droughts [MOREIRA et al. 2016] due to its simplicity ,its robustness, and flexibility for drought analysis as it can be used at different time scales (e.g., weekly, monthly, yearly) [HAYES et al. 1999].

The last century in African was marked by drought phenomenon which affected many counties and caused colossal economic loss [OBA, LUSIGI 1987; SiRCOULON 1976] Algeria was not an exception, according to the studies of MEDJERAB, HENIA et al. [2005] the North West of Algeria experienced in the two last decades a severe drought characterized by rainfall deficits varying from $12 \%$ to $20 \%$.

The studies of KETTAB et al. [2004] conducted for the period between 1980 and 1990 noted a rainfall deficit of about $50 \%$ in the central regions of Algeria, while it come up to $30 \%$ in the westernand the eastern parts.

At a larger regional scale, LABORDE [1993] studied rainfall data of 120 stations Northern Algeria, the results indicated an alternation of wet and dry sequences; (i) a long wet sequence from 1922 to 1938 characterized by rainfall excess of about $6 \%$. (ii) A dry sequencefrom 1939 to 1946 in the eastern and the centre parts of Algeria with a rainfall deficit of about 11\%. (iii) A wet sequence from 1947 to 1972 (iiii) and a long dry sequence that starts from 1973.

This paper aims at assessing the spatial and temporal evolution of drought over the Seybouse watershed (North-eastern Algeria) for the period between 1970 and 2011 by analysing precipitation series using a number of tests (Mann-Kendall, Sen's slope estimator, Pettitt) and by calculating and mapping the standardized precipitation index $(S P I)$.

\section{STUDY AREA AND DATA}

\section{STUDY AREA}

The Seybouse watershed which covers an area of $6471 \mathrm{~km}^{2}$ is located in the North East of Algeria between the latitudes $36^{\circ} 15^{\prime}$ and $37^{\circ} 00^{\prime}$ North and the longitudes $7^{\circ} 15^{\prime}$ and $7^{\circ} 55^{\prime}$ East, it is part of the Hydrographic Region Constantine - Seybouse Mellegue, bordered North by the Mediterranean Sea and south by the high plateaus of Constantine (Fig. 1). The study area is characterized by a Mediterranean climate with hot and dry summer, and cold and rainy winter. The mean annual rainfall ranges from 1167.96 $\mathrm{mm}$ at Mechrouha to $507.97 \mathrm{~mm}$ at Ain Makhlouf (Tab. 2), which indicates a heterogeneous spatial distribution of rainfall over the study area. The Seybouse watershed has three main watercourses which are the Bouhamdane, the Charef and the Seybouse rivers. The Seybouse River begins in Medjaz Amar at the confluence of the two other rivers and runs for about $225 \mathrm{~km}$

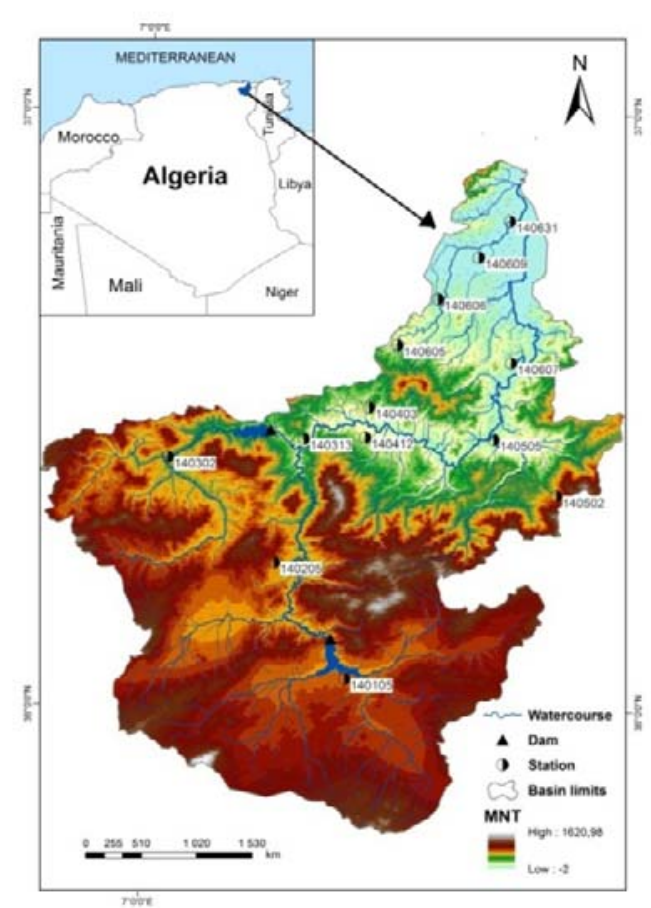

Fig. 1. Map of the Seybouse watershed and hydrometric station; source: own elaboration

North ending in the South-East of Annaba city into the Mediterranean Sea with an average annual flow of $11.5 \mathrm{~m}^{3} \cdot \mathrm{s}^{-1}$.

\section{RAINFALL DATA}

The study of climate requires long and many series of observations. The quality of data represents a major element in these studies [MEDDI, HUBERT 2003]. In this study, 13 rainfall stations (Tab. 1) managed by the National Agency of Water Resources (ANRH) was used to create as possible the most complete and representative annual data-base of the zone of study (Fig. 1). The data collected from these stations follow the criteria of quality and quantity. The series of observations taken into account spread over 42 years between 1970 and 2011 .

Table 1. Characteristics of rainfall stations in the Seybouse watershed

\begin{tabular}{|l|c|c|c|}
\hline \multicolumn{1}{|c|}{ Stations } & $x$ & $y$ & Code \\
\hline Pont Bouchet & 387676.538 & 4075860.31 & 140631 \\
\hline Ain Barda & 374436.463 & 4061429.10 & 160606 \\
\hline Nechmeya & 366951.782 & 4052869.16 & 140605 \\
\hline Boukamouza & 387853.440 & 4049493.79 & 140607 \\
\hline Bouchegouf & 384626.796 & 4035289.75 & 140505 \\
\hline Guelma (Fendjel) & 360987.538 & 4035719.82 & 140412 \\
\hline Heliopolis & 361718.010 & 4041294.87 & 140403 \\
\hline Mechrouha & 396191.581 & 4024729.98 & 140502 \\
\hline El Karma & 381949.053 & 4069154.17 & 140609 \\
\hline Medjaz Amar & 349708.384 & 4035499.41 & 140313 \\
\hline Ain Makhlouf & 344190.352 & 4012483.12 & 140205 \\
\hline Charef (El Khenga) & 357146.418 & 3990797.14 & 140105 \\
\hline Ain Sabath & 324651.829 & 4032145.71 & 140302 \\
\hline
\end{tabular}

Source: National Agency of Water Resources [ANRH 2009]. 
The principal statistical characteristics of the rainfall series are presented in the Table 2.

The statistical analysis conducted on the annual rainfall series shows that their distribution is Asymmetric. We noted also a significant difference between the position's parameters (average, median). The co- efficient of variation for annual rainfall is characterized by high fluctuations especially at the stations Mechrouha and Nechmeya where the coefficient of variation is at $43 \%$ and $40 \%$ respectively, while it ranges from $24 \%$ and $33 \%$ at the other stations.

Table 2. Statistical characteristics of the rainfall data

\begin{tabular}{|c|c|c|c|c|c|c|c|c|c|}
\hline \multirow{2}{*}{ Station } & Mean rainfall & Median & Minimum & Maximum & \multirow{2}{*}{$\begin{array}{l}\text { Standard } \\
\text { deviation }\end{array}$} & \multirow{2}{*}{$\begin{array}{c}\text { Coefficient of } \\
\text { variation }\end{array}$} & \multirow{2}{*}{$\begin{array}{c}\text { Coefficient of } \\
\text { skewness }\end{array}$} & \multirow{2}{*}{$\begin{array}{l}\text { Sen's } \\
\text { slope }\end{array}$} & \multirow{2}{*}{$\begin{array}{l}p \text { value } \\
\text { of MK }\end{array}$} \\
\hline & \multicolumn{4}{|c|}{$\mathrm{mm}$} & & & & & \\
\hline Pont Bouchet & 602.64 & 590.40 & 349.64 & 933.60 & 155.84 & 0.26 & 0.37 & 5.170 & 0.010 \\
\hline Ain Berda & 630.88 & 595.80 & 368.20 & 973.00 & 153.14 & 0.24 & 0.22 & 3.425 & 0.114 \\
\hline Bouchegouf & 547.96 & 537.65 & 279.30 & 884.00 & 150.22 & 0.27 & 0.42 & 1.926 & 0.343 \\
\hline Boukamouza & 685.07 & 675.40 & 380.50 & 1212.91 & 198.55 & 0.29 & 0.49 & 4.019 & 0.187 \\
\hline El Kerma & 608.43 & 601.54 & 296.30 & 976.08 & 174.97 & 0.29 & 0.21 & 6.921 & 0.004 \\
\hline Guelma & 531.68 & 530.00 & 222.60 & 802.00 & 141.95 & 0.27 & 0.00 & 2.219 & 0.262 \\
\hline Heliopolis & 581.26 & 547.05 & 279.10 & 1100.20 & 170.42 & 0.29 & 0.85 & 0.219 & 0.863 \\
\hline Mechrouha & 1167.96 & 1066.40 & 298.60 & 2158.24 & 498.30 & 0.43 & 0.10 & 24.844 & 0.001 \\
\hline Medjaz Amar & 561.68 & 534.00 & 309.10 & 946.40 & 1593.01 & 0.28 & 0.40 & 5.503 & 0.005 \\
\hline Nechmeya & 593.66 & 527.17 & 264.95 & 1353.46 & 239.79 & 0.40 & 1.10 & 6.654 & 0.013 \\
\hline Ain Makhlouf & 507.97 & 490.60 & 107.19 & 1176.10 & 166.03 & 0.33 & 1.56 & -0.461 & 0.763 \\
\hline Charef & 574.24 & 546.03 & 343.90 & 1065.60 & 165.87 & 0.29 & 1.14 & 1.145 & 0.682 \\
\hline Bordj Sabath & 542.19 & 538.75 & 264.30 & 928.50 & 151.70 & 0.28 & 0.76 & 3.740 & 0.048 \\
\hline
\end{tabular}

Source: own study.

\section{METHODS}

\section{ANALYSES OF THE HOMOGENEITY OF THE RAINFALL DATA}

Homogeneity of rainfall data was performed to define the trends and the change points in the annual rainfall time series using: (i) the Mann-Kendal test, (ii) Sen's slope, and (iii) the Pettitt test.

\section{MANN-KENDALL TEST}

The non-parametric Mann-Kendall (MK) test proposed by MANN [1945] and extended by KENDALL et al. [1975] is used in this study to detect trends in rainfall data. This technique recognizes any trend in a given time series, without specifying whether the trend is linear or not [HISDAL et al. 2001]. The MK test was widely used to test the trend of meteorological and hydrological data as it accepts missing values in the time series [PATRA et al. 2012; PINGALE et al. 2015; 2016; Wu et al. 2008].

Test statistic $S$ defined as [TAXAK et al. 2014]:

$$
S=\sum_{i-1 j}^{n-1} \sum_{i+1}^{n} \operatorname{sgn}\left(x_{j}-x_{i}\right)
$$

where: $x_{j}=$ the sequential data values; $n=$ length of the data set

$$
\operatorname{sgn}(y)=\left\{\begin{array}{c}
1 \ldots \text { if } y>0 \\
0 \ldots \text { if } y=0 \\
-1 \ldots \text { if } y<0
\end{array}\right.
$$

It has been documented that when $n \geq 8$, the statistic $S$ is approximately normally distributed with the mean $E(s)=0$ and variance as

$$
V(S)=\frac{n(n-1)(2 n+5)-\sum_{i-1}^{m} t_{i}\left(t_{i}-1\right)\left(2 t_{i}+5\right)}{18}
$$

where: $m=$ the number of tied groups; $t_{i}=$ the size of the $i^{\text {th }}$ tied group.

Monte Carlo simulation was used to assess the statistical significance of the trends at a significance level of $5 \%$. At this level, a positive trend is significant when $p$-value $>0.05$, and a negative trend is significant when its $p$-value $<0.05$ [FINIGURE et al. 2016; YUE, PILON 2004]. The null hypothesis $H_{0}$ assumes that there is no trend in the series, which means that they are homogeneous [DOUGLAS et al. 2000].

\section{SEN'S SLOPE ESTIMATOR}

The trend magnitude is estimated using a nonparametric median based slope estimator proposed by SEN [1968] and HIRSCH et al. [1984]. The Sen's slope is given by the following expression [SALARIJAZI et al. 2012]:

$$
\beta=\operatorname{median}\left[\frac{x_{j}-x_{k}}{j-k}\right] \text { for all } k<j
$$

where: $1<k<j<n$, and $\beta$ is considered as median of all possible combinations of pairs for the whole data set.

\section{CHANGE POINT TEST}

The change point test proposed by PETTITT [1979] derived from the Mann-Whitney statistical test is adopted in this study to identify the presence and timing of non-stationarity in the form of an abrupt 
shift in the mean annual rainfall series. It is a nonparametric test that requires no assumption about the distribution of data. This test has been widely used to detect change points in the observed meteorological and hydrological time series [TAXAK et al. 2014].

The change point $t$ is detected by determining if the mean time series can be divided in two statistically different series before and after $t$. The null hypothesis $H_{0}$ states that no shift exists in the time series at time $t$ which means that both means of the subseries are consistent. The alternative hypothesis $H a$ is that change-point exists at time $t$, in which $t=1, \ldots, n$ as all possible subdivisions of the time series are measured, since $t$ is unknown here [ISHAK 2014].

In the present study, the significance of the test is assessed using the Monte Carlo resampling procedure which computes the corresponding $p$-values at the level of significance of $5 \%$. At this level, a changepoint exists when $p$-value $<0.05$.

\section{ANALYSIS OF THE RAINFALL DATA BY PLUVIOMETRIC INDICES}

The standardized precipitation index $(S P I)$ method proposed by MCKEE et al. [1993; 1995] was employed in this study to analyse the rainfall data by identifying dry and wet sequences and assessing the severity of drought. As over-mentioned the SPI method is a highly recommended technique, as well it was employed in several researches all around the world [AWANGE et al. 2016; BONACCORSO et al. 2003; HAYES et al. 1999; ZHOU, LIU 2016].

The calculation of SPI requires at least 30 years of rainfall data which allow evaluating the probability distribution function, this latter is normalized to have the mean of zero. The values of SPI are expressed in standard deviations where positive SPI indicating greater than median rainfall designate wet condition, while negative values indicating less than median rainfall designate wet condition [EDWARDS et al. 1997].

Mathematically the $S P I$ is calculated using the following expression:

$$
S P I=\frac{1\left(P_{i}-P_{m}\right)}{\sigma}
$$

where: $P_{i}=$ the actual rainfall $(\mathrm{mm}), P_{m}=$ the mean rainfall, $\sigma=$ the standard deviation.

Drought severity is identified through SPI values according to the classification scheme (Tab. 3) pro-

Table 3. Classification of drought severity based on SPI

\begin{tabular}{|l|c|}
\hline \multicolumn{1}{|c|}{ Drought category } & $S P I$ classification \\
\hline Extremely wet & $S P I \geq 2$ \\
\hline Very wet & $1 \leq S P I<2$ \\
\hline Moderately wet & $0 \leq S P I<1$ \\
\hline Moderately dry & $-1<S P I<0$ \\
\hline Severely dry & $-2<S P I \leq-1$ \\
\hline Extremely dry & $S P I \leq-2$ \\
\hline
\end{tabular}

Source: MCKEE et al. [1993], modified. posed by MCKEE et al. [1993], and used in several studies in the Maghreb region [ALI, LEBEL 2009; ARDOIN-BARDIN 2004; ARDOIN-BARDIN et al. 2003; BergaOUi, AlOUINI 2002].

\section{RESULTS AND DISCUSSION}

\section{HOMOGENEITY ANALYSIS}

The results of the Mann-Kendall test (Tab. 2) indicated that the null hypothesis $H o$ is accepted for Ain Berda, Bouchegouf, Boukamouza, Guelma, Heliopolis, Ain Makhlouf, and Charef stations ( $p$-value > $0.05)$, with magnitudes of trends equal, respectively, to $0.1141,0.3426,0.1875,0.2617,0.8633,0.7631$, 0.6824 . The mentioned stations present certain homogeneity of annual rainfall data at 5\% level of significance. On the other hand, the probability of the null hypothesis is rejected for Pont Bouchet, El Kerma, Mechrouha, Medjaz Amar, Nechmeya and Bordj Sabath stations with magnitudes of trends equal, respectively, to $0.0099,0.0038,0.0004,0.0054,0.0129$ and 0.0482 .

According to Sen slope estimates at 5\% level of significance (Tab. 2), only Ain Makhlouf station showed a negative trend $(-0.461)$. The other stations showed significant positive trends ranging from 0.219 (Heliopolis) to 24.844 (Mechrouha).

Table 4 illustrates the results of the change point test of Pettitt conducted on the mean annual rainfall of the 13 stations of the Seybouse watershed.

Table 4. Results of Pettitt test

\begin{tabular}{|l|c|c|c|}
\hline \multicolumn{1}{|c|}{ Station } & $p$-value & Year & Trend \\
\hline Pont Bouchet & 0.0472 & 2001 & Ha \\
\hline Ain Berda & 0.1255 & 2001 & Ho \\
\hline Bouchegouf & 0.3865 & 1994 & Ho \\
\hline Boukamouza & 0.2941 & 2000 & Ho \\
\hline El Kerma & 0.0044 & 2001 & Ha \\
\hline Guelma & 0.6165 & 2001 & Hо \\
\hline Heliopolis & 0.7774 & 2001 & Hо \\
\hline Mechrouha & 0.0001 & 1996 & На \\
\hline Medjaz Amar & 0.0116 & 1982 & На \\
\hline Nechmeya & 0.0113 & 1989 & На \\
\hline Ain Makhlouf & 0.9056 & - & Но \\
\hline Charef & 0.1645 & - & Но \\
\hline Bordj Sabath & 0.1063 & 2001 & Но \\
\hline
\end{tabular}

Explanations: $\mathrm{Ha}=$ heterogeneous series, $\mathrm{Ho}=$ homogenous series. Source: own study.

The results show that the mean annual rainfall series of Pont Bouchet, El Kerma, Mechrouha, Medjaz Ammar and Nechmaya stations have significant change points that occurred between 1982 and 2001 (Fig. 2), the hypothesis of homogeneity is rejected for these stations at $5 \%$ level of significance. The test indicated also that the hypothesis of homogeneity is valid in the other stations as Non-significant change points were detected in their rainfall series ( $p$ value $\geq$ $0.05)$. 

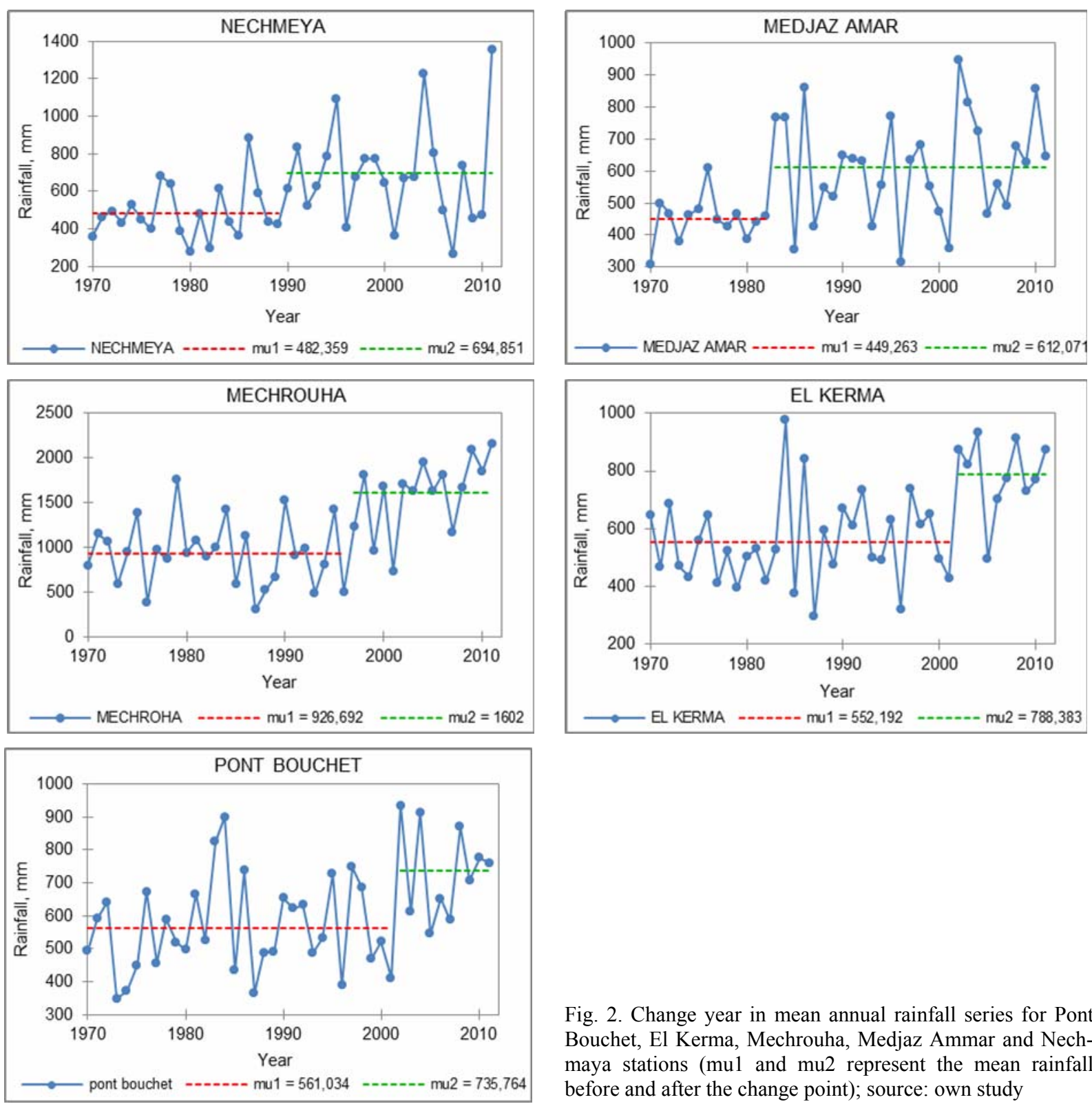

\section{RAINFALL ANALYSIS BY PLUVIOMETRIC INDEX}

The SPI indices were calculated for the 13 rainfall stations of the Seybouse basin in order to differentiate dry, normal, and wet periods and to better evaluate the variations in the annual rainfall over the Seybouse basin.

In the $70 \mathrm{~s}$, the 80 s and early $90 \mathrm{~s}$, with the exception of Mechrouha station, we observed mostly negative SPI values which are often less than -1 (Fig. 3).

In the mid-90s until 2011, with the exception of Ain Makhlouf and Guelma stations, we observed mostly positive SPI values which are often greater than 1, negative SPI values are less frequent (Fig. 3).

According to the table below which presents the statistical characteristics of the 5 years average SPI indices, the studied period can be divided in two sequences; a dry sequence that begins in 1970 and ends in 1994 with negative average SPI values that range

Fig. 2. Change year in mean annual rainfall series for Pont Bouchet, El Kerma, Mechrouha, Medjaz Ammar and Nechmaya stations (mu1 and mu2 represent the mean rainfall before and after the change point); source: own study

from -0.54 to -0.07 , and a wet sequence from 1995 to 2011 with positive average $S P I$ values that range from 0.06 to 0.85 .

Figure 4 illustrates the spatial and temporal variability of the pluviometric indices over the Seybouse basin; the maps were created in geographic information system (GIS) environment by interpolating SPI values of the 13 stations using a Kriging interpolation type.

According to the SPI maps, during the period 1970-1994, deficit of rainfall associated with (i) moderately dry conditions were widely observed through the Seybouse watershed, (ii) and with extremely dry conditions recorded in some limited areas (Medjaz Ammar in 1970-1974 and Charef in 19851989). This period was also marked by an excess of rainfall associated with moderately wet conditions which was persistent in the central-eastern area (Mechrouha). 

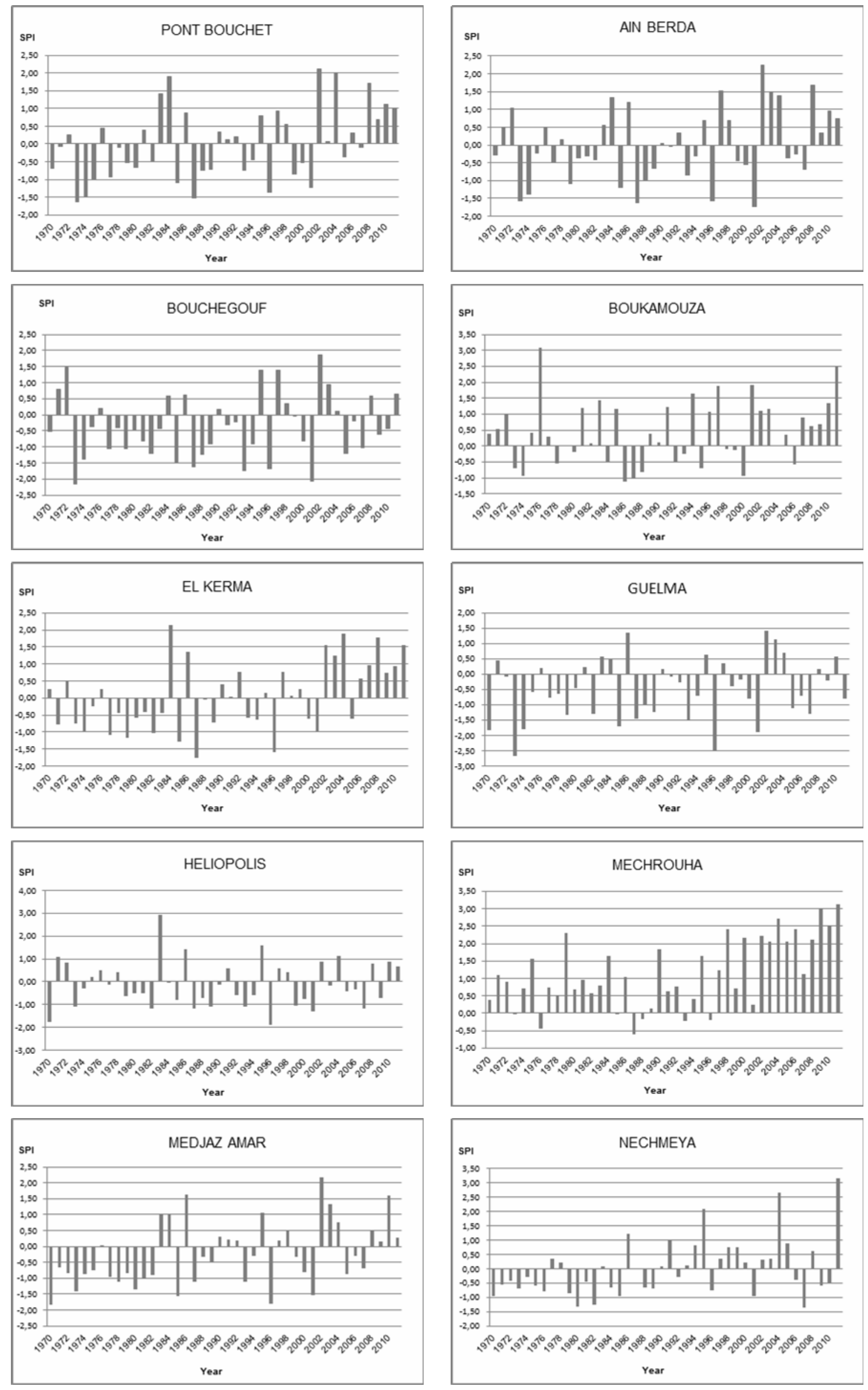

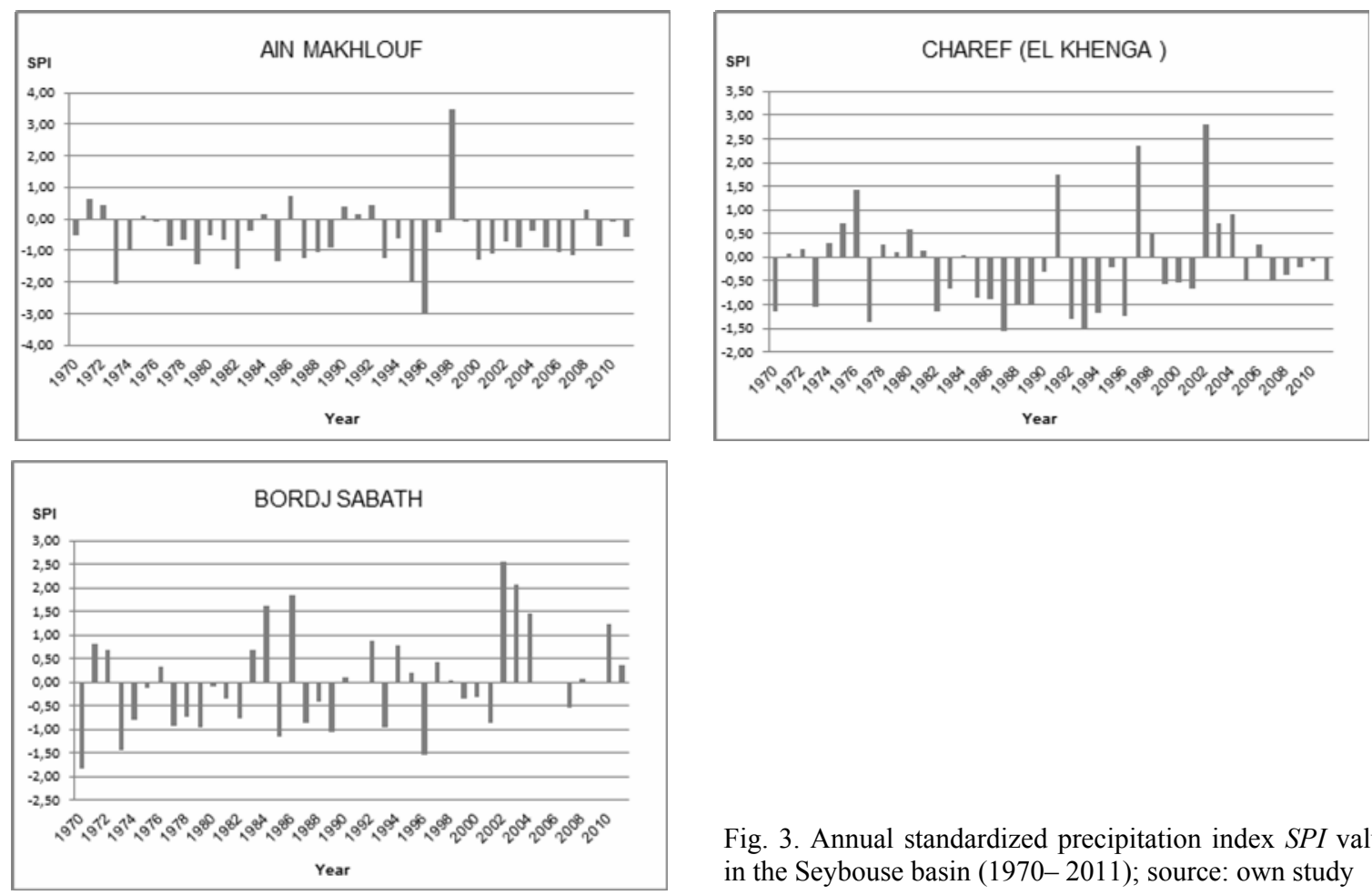

Fig. 3. Annual standardized precipitation index $S P I$ values in the Seybouse basin (1970-2011); source: own study

Table 5. Statistical characteristics of the 5 years average $S P I$ values for the study area

\begin{tabular}{|c|c|c|c|c|c|c|c|c|c|c|}
\hline \multirow[b]{2}{*}{ Characteristics } & \multicolumn{5}{|c|}{ Dry cycle } & \multicolumn{4}{|c|}{ Wet cycle } & \multirow[b]{2}{*}{ 1970-2011 } \\
\hline & $\begin{array}{c}1970- \\
1974\end{array}$ & $\begin{array}{c}1975- \\
1979\end{array}$ & $\begin{array}{c}1980- \\
1984\end{array}$ & $\begin{array}{c}1985- \\
1989\end{array}$ & $\begin{array}{c}1990- \\
1994\end{array}$ & $\begin{array}{c}1995- \\
1999\end{array}$ & $\begin{array}{c}2000- \\
2004\end{array}$ & $\begin{array}{c}2005- \\
2009\end{array}$ & $\begin{array}{c}2010- \\
2011\end{array}$ & \\
\hline Average & $-0,43$ & $-0,21$ & $-0,003$ & $-0,54$ & $-0,07$ & 0,12 & 0,46 & 0,06 & 0,85 & 0,03 \\
\hline Minimum & $-1,19$ & $-0,73$ & $-0,72$ & $-1,06$ & $-0,60$ & $-0,42$ & $\begin{array}{ll}-0,88 \\
\end{array}$ & $-0,73$ & $-0,32$ & $-1,19$ \\
\hline Maximum & 0,61 & 0,94 & 0,92 & 0,07 & 0,68 & 1,16 & 1,88 & 2,14 & 2,81 & 2,81 \\
\hline Standard deviation & 0,46 & 0,52 & 0,47 & 0,31 & 0,39 & 0,44 & 0,63 & 0,76 & 0,89 & 0,19 \\
\hline Average deviation & 0,32 & 0,42 & 0,37 & 0,25 & 0,30 & 0,32 & 0,41 & 0,54 & 0,64 & 0,09 \\
\hline
\end{tabular}

Source: own study.

During the period 1995-2011, a gradually return to normal precipitation is observed; moderately wet and very wet conditions were recorded in the most areas of the Seybouse watershed, with different spatial extents. Though, the deficit of rainfall persists in the center of the basin (Guelma, Ain Makhlouf) over the entire period.

\section{CONCLUSIONS}

In this study drought analysis was conducted in the Seybouse watershed for the period between 1970 and 2011 by analysing rainfall data using non-parametric tests and the SPI method.

The statistical analysis of the rainfall data indicated that the evolution of the mean annual rainfall series is characterized by significant irregularities expressed by significant coefficients of variation and a statistically significant increase in the mean annual rainfall. As well, the climatic variability in the study area was confirmed by the Pettitt test which detected the presence of shifts in the mean annual rainfall series. These shifts were significant at 5 stations from the 13 stations under study.
According to the standardized precipitation index calculations the studied period was divided in two sequences; a dry sequence from 1970 to 1999 , and a wet sequence from 1999 to 2011, which is in good agreement with the results obtained by LABORDE [1993]. Which noted a significant rainfall downward in the North of Algeria after the 70s and agrees as well with the studies of KHOUALDIA et al. [2014] which indicated the return of normal precipitation between 2001 and 2007

The interpolation of SPI indices on the entire ba$\sin$ shows a heterogonous distribution of rainfall through the Seybouse basin either in the dry cycle or in the wet cycle and showed that the central part of the Seybouse basin was affected by persistent drought conditions.

The study results constitute valuable material that can be used in forecasting droughts in the Seybouse watershed which permits effective planning and management of water resources and agriculture activities, and moreover, elaborating adaptation measures to face drought periods. 

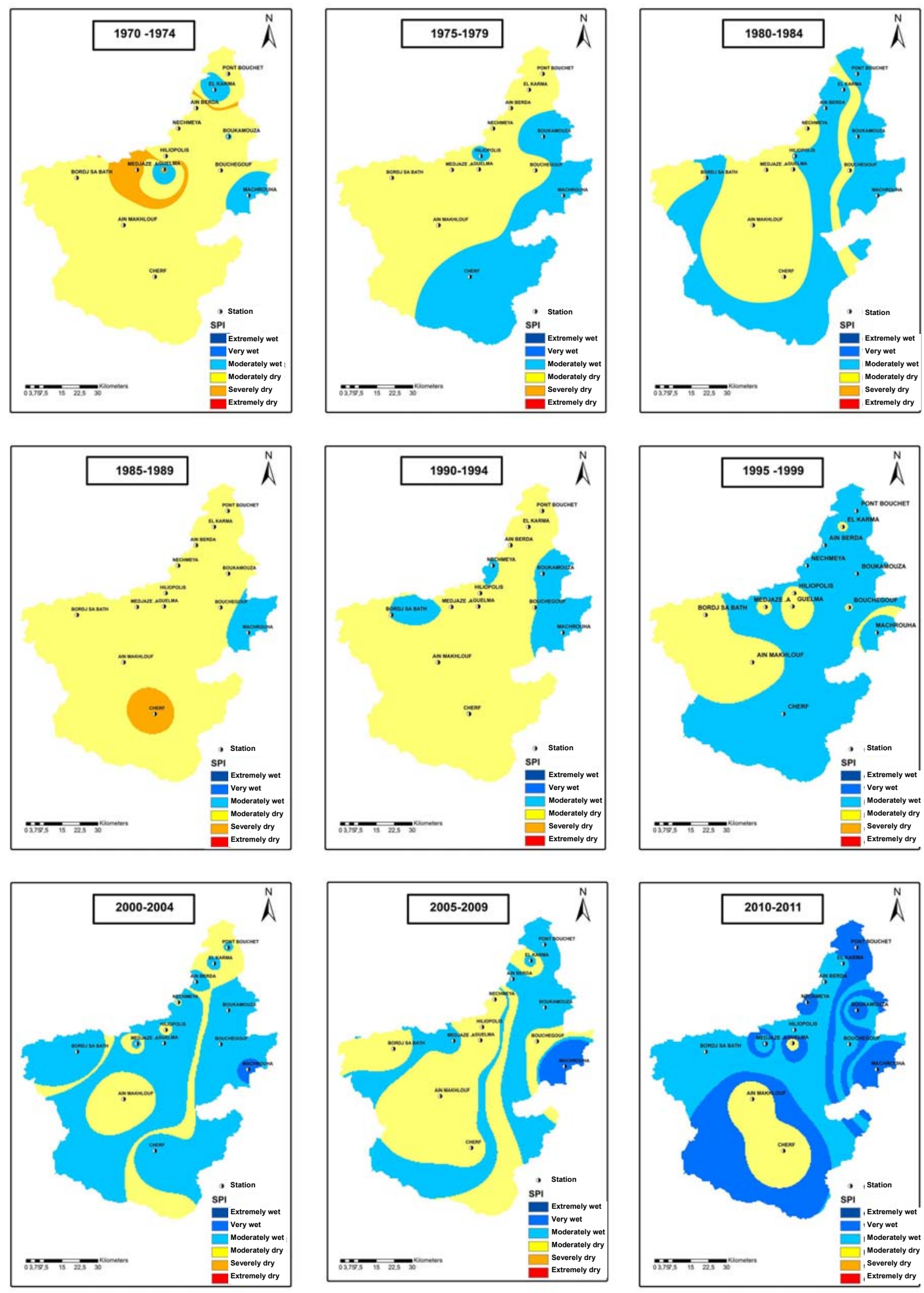

Fig. 4. Spatiotemporal monitoring of drought using standardized precipitation index (SPI), 1970-2011; source: own study 


\section{REFERENCES}

Ali A., LeBel T. 2009. The Sahelian standardized rainfall index revisited. International Journal of Climatology. Vol. 29. No. 12 p. 1705-1714.

ARDOIN-BARDIN S. 2004. Variabilité hydro climatique et impacts sur les ressources en eau de grands bassins hydrographiques en zone soudano-sahélienne [Hydroclimatic variability and its impacts on the water resources of large watersheds in the Soudan-Sahelian area]. Doctoral dissertation. Paris. UNESCO.

Ardoin-Bardin S., Dezetter A., Servat E., Mahe G., Paturel J.E., Dieulin C., Boyer J.F. 2003. Analyse de la variabilité des ressources en eau en Afrique de l'Ouest sahélienne par modélisation hydrologique à grand pas de temps et d'espace [Analysis of the variability of water resources in the Africa's West Sahelian using hydrological modeling at large time and space steps]. Journal de l'Eau et de l'Environnement. Vol. 3 p. 5-13.

Awange J.L., Mpelasoka F., Goncalves R.M. 2016. When every drop counts: Analysis of droughts in Brazil for the 1901-2013 periods. Science of the Total Environment. Vol. 566 p. 1472-1488.

BALling JR R.C., Vose R.S., WeBer G.R. 1998. Analysis of long-term European temperature records 1751-1995. Climate Research. Vol. 10. No. 3 p. 193-200.

Bergaoui M., Alouini A.W.S. 2002. Caractérisation de la sécheresse météorologique et hydrologique: Cas du bassin versant de Siliana en Tunisie [Characterization of meteorological and hydrological droughts: Case of Silana basin in Tunisia]. Science et changements planétaires/Sécheresse. Vol. 12. No 4 p. 205-213.

Bonaccorso B., Bordi I., CANCElliere A., Rossi G., SUTERA A. 2003. Spatial variability of drought: An analysis of the SPI in Sicily. Water Resources Management. Vol. 17. No. 4 p. 273-296.

Douglas E.M, Vogel R.M., Kroll C.N. 2000. Trends in foods and low flows in the United States: Impact of spatial correlation. Journal of Hydrology. Vol. 240 p. 90105.

Edwards C.D.C., McKee T.B., Doesken N.J., Kleist J. 1997. Historical analysis of drought in the United States. In 77th Conference on climate variations, 77th AMS Annual Meeting. 2-7 February. Long Beach, California. Vol. 27 p. 129-139.

FNiguire F., LAFtouhi N.E., SAidi M.E., Zamrane Z., El Himer H., KHALIL N. 2016. Spatial and temporal analysis of the drought vulnerability and risks over eight decades in a semi-arid region (Tensift basin: Morocco). Theoretical and Applied Climatology p. 1-10. DOI: 10.1007/s00704-016-1873.

ISHAK E.H. 2014. Effects of climate variability and change on flood magnitude and frequency in Australia. $\mathrm{PhD}$ thesis. Sydney, Australia. University of Western Sydney.

Han Zhou, YuAnBo LiU 2016. SPI based meteorological drought assessment over a humid basin: Effects of processing schemes. Water. Vol. 8. Iss. 9, 373. DOI: 10. 3390/w8090373.

Hayes M.J., Wilhite D.A., Svoboda M.D., Wilhite D.A., VANYARKHO O.V. 1999. Monitoring the 1996 drought using the standardized precipitation index. Bulletin of the American Meteorological Society. Vol. 80. No. 3 p. 429-438.

He M., GautAm M. 2016. Variability and trends in precipitation, temperature and drought indices in the State of
California Hydrology. Vol. 3. No. 2, 14. DOI: 10.3390/ hydrology3020014.

HiRSCH R.M., SLACK J.R. 1984. A nonparametric trend test for seasonal data with serial dependence. Water Resources Research. Vol. 20. No. 6 p. 727-732.

Hisdal H., Stahl K., Tallaksen L.M., Demuth S. 2001. Have streamflow droughts in Europe become more severe or frequent. International Journal Climatology. Vol. 21. No. 3 p. 317-333. DOI: 10.1002/joc.619.

Kendall M.G. 1975. Rank correlation methods. $4^{\text {th }}$ ed. London. Charles Griffin pp. 202.

Kettab A., Mouhoub A., Ouarda T., Bobbee B. 2004. Contribution a l'étude du phénomène de la sécheresse sur les régions littorales de l'Algérie [Contribution to the study of the drought phenomenon in the littoral of Algeria]. Colloque international sur l'eau. Chlef, 05/06/ février, Algérie p. 12.

Khoualdia W., DJebBar Y., Hammar Y. 2014. Caractérisation de la variabilité climatique: cas du bassin versant de La Medjerda (Nord-Est algérien) [Climatic variability characterisation: Case of Medjerda watershed (northeastern Algeria)]. Synthèse: Revue des Sciences et de la Technologie. Vol. 29. No. 1 p. 6-23.

LABORDE J.P. 1993. Carte pluviométrique de l'Algérie du Nord à l'échelle du 1/500 000, Notice explicative. Project PNUD/ALG/88/021. Alger. Agence nationale des resources hydrauliques [Explicative notice Algiers, the National Agency of Hydraulic Resources]. Pluviometric map of Northern Algeria scale of 1/500 000 .

MANN H.B. 1945. Nonparametric test against trend. Econometrica. Vol. 13 p. 245-259.

McKee T.B., Doesken N.J., Kleist J. 1995. Drought monitoring with multiple time scales. In: Proceedings of the $9^{\text {th }}$ Conference on Applied Climatology, AMS, Dallas, TX p. 233-236.

McKee T.B., Doesken N.J., Kleist J. 1993. The relationship of drought frequency and duration to time scales. In: Proceedings of the $8^{\text {th }}$ Conference on Applied Climatology. Anaheim, CA. AMS p. 179-184.

MedDi M., HuberT P. 2003. Impact de la modification du régime pluviométrique sur les ressources en eau du Nord-Ouest de l'Algérie [Impact of rainfall regime change on water resources in North-western Algeria]. Hydrology of die Mediterranean and Semiarid Regions. Proceedings of an international symposium. Montpellier, April 2003. IAHS Publications. No. 278 p. 229235.

Medjerab A., Henia L. 2005. Régionalisation des pluies annuelles dans l'Algérie Nord-occidentale [Regionalization of annual rainfall in North-western Algeria]. Revue Géographique de l'Est. Vol. 45. No 2.

Moreira E.E., PIRES C.L., Pereira L.S. 2016. SPI drought class predictions driven by the North Atlantic Oscillation Index Using Log-Linear Modeling. Water. Vol. 8. Iss. 2, 43. DOI: 10.3390/w8020043.

NiCHOLSON S.E. 1989. Long term changes in African rainfall. Weather. Vol. 44. No 2 p. 46-56.

OBA G., LUSIGI W.J. 1987. An overview of drought strategies and land use in African pastoral systems. Overseas, Development Institute Agricultural Administration Unit. Paper 23a pp. 29.

PALMER W.C. 1965. Meteorological drought. Weather Bureau. Research Paper. No. 45 pp. 58.

Patra J.P., Mishra A., Singh R., Raghuwanshi N.S. 2012. Detecting rainfall trends in twentieth century (18712006) over Ornoa State, India. Climatic Change. Vol. 111. No. 3-4 p. 801-817. 
Pettitt A.N. 1979. A non-parametric approach to the change-point problem. Applied Statistics. Vol. 28. No. 2 p. 126-135.

Pingale S., AdAmowski J., Jat M., Khare D. 2015. Implications of spatial scale on climate change assessments. Journal of Water and Land Development. Vol. 26. No. 1 p. $37-55$.

Pingale S.M., Khare D., Jat M.K., Adamowski J. 2016 Trend analysis of climatic variables in an arid and semiarid region of the Ajmer District, Rajasthan, India. Journal of Water and Land Development. Vol. 28. No. 1 p. $3-18$.

Salarijazi M., AKHOND-Ali A.M., Adib A., DaneshKhaH A. 2012. Trend and change-point detection for the annual stream-flow series of the Karun River at the Ahvaz hydrometric station. African Journal of Agricultural Research. Vol. 7. No. 32 p. 4540-4552.

SEN P.K. 1968. Estimates of the regression coefficient based on Kendall's tau. Journal of the American Statistical Association. Vol. 63. No. 324 p. 1379-1389.

SiRCOULON J. 1976. Les données hydro-pluviométriques de la sécheresse récente en Afrique intertropicale: Comparaison avec les sécheresses "1913" et "1940" [Hydropluviometric data of the recent drought in tropical Africa: Comparison with drought of 1913 and 1940]. Cahiers ORSTOM. Série Hydrologie. Vol. 13. No. 2 p. $75-174$.

TAXAK A.K., MurumKar A.R., ARYA D.S. 2014. Long term spatial and temporal rainfall trends and homogeneity analysis in Wainganga basin, Central India. Weather and Climate Extremes. Vol. 4 p. 50-61.

VAN Rooy M.P. 1965. A rainfall anomaly index (RAI) independent of time and space. Notos. Vol. 14 p. 43-48.

VinNiKov K.Y., GROISMAN P.Y., Lugina K.M. 1990. Empirical data on contemporary global climate changes (temperature and precipitation). Journal of Climate. Vol. 3. No. 6 p. 662-677.

Wilhite D.A., GlantZ M.H. 1985. Understanding: the drought phenomenon: the role of definitions. Water International. Vol. 10. No. 3 p. 111-120.

Wu H., Hayes M.J., Wilhite D.A., Svoboda M.D. 1999. Monitoring the 1996 drought using the standardized precipitation index. Bulletin of the American Meteorological Society. Vol. 80. No. 3 p. 429-438.

Wu H., SOH L.K., SAMAl A., ChEN X.H. 2008. Trend analysis of stream flow drought events in Nebraska. Water Resources Management. Vol. 22. No. 2 p. 145-164.

YuE S., PILON P. 2004. A comparison of the power of the test, Mann-Kendall and bootstrap tests for trend detection. Hydrological Sciences Journal. Vol. 49. Iss. 1 p. 21-37.

ZHAI P.M., PAN X.H. 2003. Change in extreme temperature and precipitation over Northern China during the second half of the 20th century. Acta Geographica Sinica. Vol. 58. No. S1 p. 1-10.

ZHOU H., LIU Y. 2016. SPI based meteorological drought assessment over a humid basin: Effects of processing schemes. Water. Vol. 8. No. 9 p. 1-16.

\section{Amina KHEZAZNA, Hocine AMARCHI, Oussama DERDOUS, Fouad BOUSAKHRIA}

\section{Monitorowanie suszy w basenie Seybouse w Algierii w ciągu ostatnich dziesięcioleci}

\section{STRESZCZENIE}

Algieria jest jednym z krajów Afryki najsilniej doświadczanych przez wpływ zmian klimatu, w szczególności przez susze, które w minionych dziesięcioleciach powodowały znaczne straty gospodarcze. W prezentowanych badaniach przeprowadzono monitoring susz w latach 1970-2011 w zlewni rzeki Seybouse, analizując zmienność i trendy rocznych opadów oraz obliczając standaryzowany indeks opadów (SPI). Wyniki dowodzą dużej zmienności opadów między latami i ukazują istotną tendencję wzrostową. Oszacowane wskaźniki suszy wskazują, że zlewnia Seybouse doświadczała w przeszłości długich okresów umiarkowanej suszy, po których następował długi okres wilgotnej pogody na większości badanych obszarów. Ponadto, interpolacja standaryzowanego wskaźnika opadu na całą zlewnię Sebouse za pomocą GIS umożliwiła wizualizację i ocenę rozwoju suszy w regionie. Powinno to pomóc decydentom w zarządzaniu zasobami wodnymi, rolnictwem i innymi rodzajami działalności, które mogą być zależne od suszy.

Słowa kluczowe: GIS, standaryzowany indeks opadu (SPI), susza, zlewnia Seybouse, zmiany klimatu 